\title{
Exploitation and Sustainable Management of the Biodiversity of the Ngaoundéré Cliff (Adamawa-Cameroon)
}

\author{
Nyasiri Jonathan ${ }^{1 *}$, Tchobsala², Ibrahima Adamou1 ${ }^{1}$ Dongock Nguemo Delphine ${ }^{1}$ \\ 1University of Ngaoundéré, Faculty of Sciences, Department of Biological Sciences P.O. Box 454, Ngaoundéré \\ 2University of Maroua, Faculty of Sciences, Department of Biological Sciences P.O. Box 814, Maroua Laboratory of Biodiversity and \\ Sustainable Development
}

*Corresponding Author

Dr. Nyasiri Jonathan

\section{Article History}

Received: 02.12.2019

Accepted: 09.12.2019

Published: 30.12 .2019

\begin{abstract}
A study was conducted on the exploitation of natural resources and the sustainable management of the vegetation of the Ngaoundéré cliff. Structured and semi-structured interviews were conducted with 350 people, 50 per village. The data obtained were supplemented by direct field observations. Data analysis using Excel, STATGRAPHICS Plus 5.0 and XLSTAT showed that farmers $(88.93 \%)$, breeders $(80.07 \%)$, craftsmen $(49.29 \%)$, hunters $(28.93 \%)$ are the main operators of the resources of the cliff. The products exploited are involved in food $(55.28 \%)$, medicine $(30.51 \%)$, crafts $(53.34 \%)$, and trade $(43.54 \%)$. The most commonly used species in the cliff are Borassus aethiopum (100\%) and Mangifera indica (100\%) in the diet, Isoberlinia doka $(68.17 \%)$ as firewood, Khaya senegalensis $(63.50 \%)$ in the medicine, Piliostigma thonningii (100\%) for artisanal use and edible NTFP $(40,63 \%)$ in the trade. Faced with this exploitation of the biodiversity of the vegetation of the cliff, a forest management plan has been developed in a spirit of community management based on the participatory approach which invites all actors and social partners to take part in the decision making based on consensus between the conservative trend and the local population.
\end{abstract}

Keywords: Exploitation, biodiversity, sustainable management, cliff, Ngaoundéré.

\section{INTRODUCTION}

Forests in Central Africa and other tropical forests represent a large reservoir of biological diversity. They are important sources of income for the countries of the subregion in both the formal and informal sectors [1]. In most Congo Basin countries, logging remains the main provider of private wage employment, particularly in remote rural areas. In this sub-region of Africa, millions of people depend on forests for the daily satisfaction of their needs: timber, timber, energy, arable land, non-timber forest products, and so on [2, 3]. Most of the earth's landscapes are currently transformed by human activities to meet the socio-economic needs of the population [4]. These results in human pressure resulting in deforestation that has reached the rate of 673,000 ha per year, an annual shrinkage rate of $0.28 \%$ in the period $2000-2005$ [3]. The fact that some countries continue to increase the amount of forest area devoted to production without sustainable management insurance is a threat in prospect [5]. Likewise, population growth and its corollary, the need for arable land and pastures, point a growing trend in deforestation. Because of their major importance for global biodiversity and the global carbon cycle [6,7], tropical forest conservation has become a global issue. The issue of conservation of biodiversity and preservation of the environment has triggered a revolution in tropical countries. Many organizations promote NTFPs in Central Africa to improve forest management and contribute to raising living standards in rural areas [8]. However, the impact of the forest sector on national economies remains poorly documented to provide the deserved visibility and sustainable management of these resources. This partly explains the growing interest that economic policy guidelines give to this sector, based on a perception that the contribution of forest resources to economic growth remains marginal [9].Cameroon's forests are rich in NTFPs. However, the sector suffers from defects that may be detrimental in the long term on the sustainable management of NTFPs, namely lack of knowledge of the resource, lack of standards of rational exploitation, lack of quality products and unclear and inefficient regulations [1]. Many difficulties still hinder the ecologically and economically profitable exploitation of special products for the State and individuals. Indeed, a major obstacle to the sustainable management of tropical forests is the scarcity of knowledge about species, stand structure, history of ecosystems and their relationship to anthropogenic and climatic disturbances [10, 11]. The potential of these products, even as an indication, is not known. In the absence of inventory data, the sustainability of the exploitation of these resources

Copyright @ 2019: This is an open-access article distributed under the terms of the Creative Commons Attribution license which permits unrestricted use, distribution, and reproduction in any medium for non commercial use (NonCommercial, or CC-BY-NC) provided the original author and source are credited. 
in Cameroon can not be projected [12]. Forest resources, in products and services, have become increasingly sought after and existing information offers little knowledge of the extent to which these resources are being used and the ability of forests to meet growing needs in quantity and quality [13]. Forest knowledge must therefore be diversified and expanded accordingly [14. In spite of numerous works carried out especially in Adamawa the works of Tchotsoua $[15,16]$ on the methods of management, the conservation, the development of the savannas and the territories of Adamawa, the works of Ibrahima et al. [17] on the influence of some zoo-anthropogenic factors on the phytodiversity of the Sudano-Guinean savannahs but no research has been done on the exploitation of natural resources on the vegetation of the Ngaoundéré cliff and the methods of co-management of this cliff.

\section{MATERIAL AND MethOdS}

\section{Study area}

The study area is in the district of Mbé, department of Vina. It is located $50 \mathrm{~km}$ from Ngaoundéré between $07^{\circ} 42.00^{\prime}$ and $07^{\circ} 48.60^{\prime}$ North latitude then between $013^{\circ} 31.80^{\prime}$ and $013^{\circ} 38.40^{\prime}$ East longitude (GPS readings). The study was conducted in seven villages (Taa-toyo, Gob-gabdo, Wack, Gop, Ndom, Karna and Tchabbal) bordering the cliff (Figure 1).

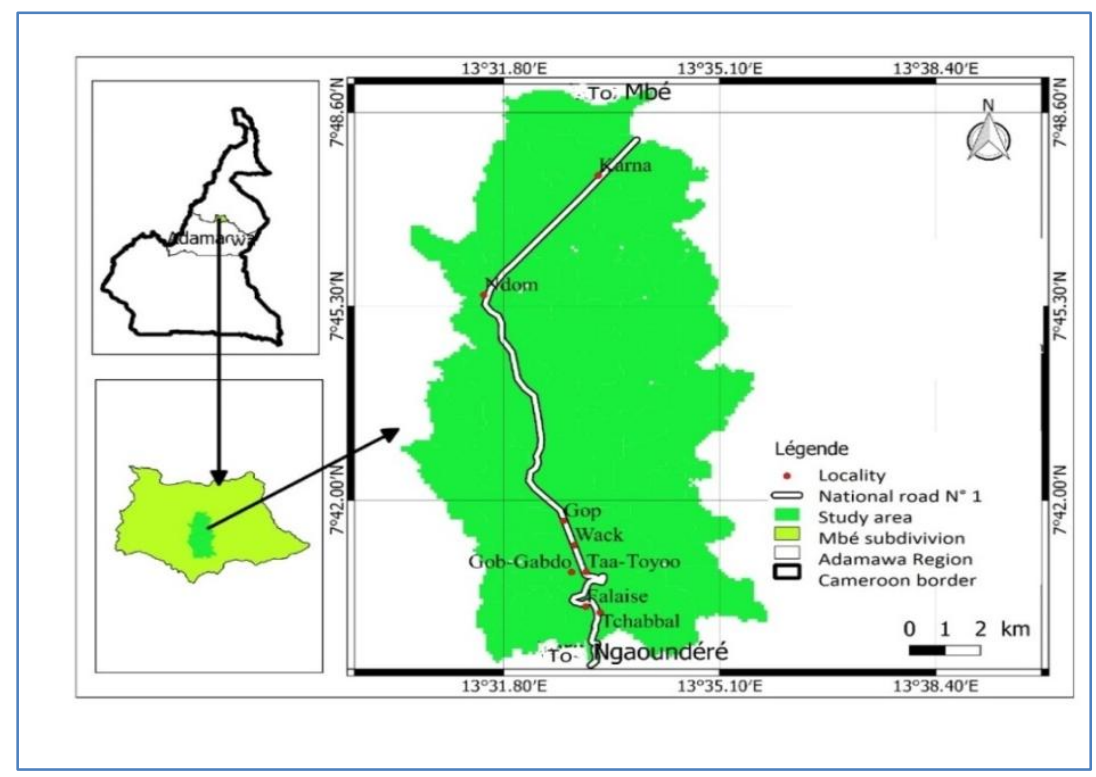

Fig-1: Location map of the study area Source: Nyasiri, 2016

The climate is of the Sudano-Guinean type, mild and cool, characterized by two seasons: a rainy season of seven months (April to October) and a dry season of seven months from October to March [18]. The average rainfall varies from $1227.9 \mathrm{~mm}$ to $1675.8 \mathrm{~mm}$. Humidity fluctuates between $64.1 \%$ and $67.6 \%$ [19]. Temperatures are rather cool with an average of $22^{\circ} \mathrm{C}$. They vary between 10 and $19^{\circ} \mathrm{C}$ for the minima during the month of December then between 27 and $34^{\circ} \mathrm{C}$ for the maxima during the month of March [18].

In the Adamawa and in particular in Ngaoundéré, the vegetation consists of open shrub savannas with the presence of species such as Adansonia digitata, Zizyphus mauritiana, Vitex doniana, Annona senegalensis, Piliostigma thonningii, Entada africana from the lateral passage of the forest dense with graminaceous and grass savannah composed of species such as Manihot esculenta, Cassia javanica, Annona squamosa, Hibiscus esculentus, Hibiscus sabdarifa, Arachis hypogaea, Pennisetum purpureum [20]. At the cliff level, vegetation is dominated by trees such as Terminalia laxiflora, Terminalia glaucescens, Isoberlinia doka, Grewia flavescens, Sarcocephalus latifolius, Pterocarpus lucens, Daniellia oliveri, Bridelia ferruginea, Annona senegalensis, Burkea africana [21-23].

In Ngaoundéré we meet the Dourou or Dii, Mboum and Baya mainly but also Massa, Kotoko, Mousgoum, Toupouri, Fulani and Moundang from the Far North of Cameroon, Bantu (Beti and Fang-Beti) arrived with the large migrations of the seventeenth century and Bamilekes and Bamouns who in the nineteenth century have infiltrated throughout the south-east of Adamawa.

The development of natural resources is mainly through agriculture, cattle breeding, beekeeping and fishing [24]. A cattle breeding occupies the first place in the local economy of Adamawa [25]. In the zone in general, the agropastoral vocation explains the strong pressure exerted on the natural resources [26].

\section{Socio-economic surveys in households}

The present work is based on ethnobotanical surveys complemented by direct observations in the field. In the seven villages (Taa-toyo, Gob-gabdo, Wack, Gop, Ndom, and Karna) surveys in the form of semi-structured and structured interviews were 
conducted with fifty (50) people per village. The questionnaires included identification variables of the respondents (name, forenames, age, sex, level of education, village) and questions concerning the activities carried out inside and on the periphery of the cliff, the perception that populations have forest space and their participation in the management of this area. Complementary surveys of the use of forest products by women, on the practices of transhumant pastoralists on the activity of professional loggers were carried out. Specific surveys were conducted among user groups that do not have a great impact on the plant resource (potters, weavers).

\section{Statistical Analysis of the Data}

Analysis of variance using the XLSTAT and STATGRAPHICS Plus 5.0 software was used to verify differences in number and surface treatments. Excel was used for averaging and histogram representation. In the presence of significant variance analyzes, mean comparisons were made using Fisher's test.

\section{RESULTS}

\section{Actors exploiting the biodiversity of the Ngaoundéré cliff}

Table 1 presents the different categories of actors exploiting the forest formation of the Ngaoundéré cliff. This table shows that six actors intervene in the exploitation of resources. Farmers $(88.93 \%)$ are the first actors of the vegetation. They practice slashand-burn agriculture in all villages. Breeders $(80.07 \%)$, the second largest group, graze their animals in the forest landscapes of the cliff. They practice bush fires as a grazing rejuvenation system. Craftsmen (49.29\%) use resources for building habitats, dyes and other handicrafts. The other groups consisting of hunters (28.93\%), blacksmiths (9.64\%) and fishermen $(6.07 \%)$ are less present in the exploitation of forest resources of the cliff. In addition, some actors, poorly represented groups are absent in some villages. These are the blacksmiths absent at Taa-toyo and Gob-gabdo and the fishermen absent at Tchabbal. In each village, the same individual exercises more than two activities at a time. The analysis of the variances reveals a significant difference between the actors $(0.000<0.001)$

Table-1: Proportion of main actors exploiting the forest formation of the cliff $(\%)$

\begin{tabular}{lcccccccc}
\hline \multicolumn{1}{c}{ Villages } & $\begin{array}{c}\text { Taa- } \\
\text { toyo }\end{array}$ & $\begin{array}{c}\text { Gob- } \\
\text { gabdo }\end{array}$ & Wack & Gop & Ndom & Karna & Tchabbal & Average \\
\hline Farmers & $95.00^{\mathrm{Aa}}$ & $92.50^{\mathrm{Bc}}$ & $90.00^{\mathrm{Ab}}$ & $75.00^{\mathrm{Ae}}$ & $85.00^{\mathrm{Ad}}$ & $90.00 \mathrm{Ab}$ & $95.00^{\mathrm{Aa}}$ & $88.93 \pm 5.10$ \\
Breeders & $67.50^{\mathrm{Ce}}$ & $80.00^{\mathrm{Ac}}$ & $87.50^{\mathrm{Bb}}$ & $75.00^{\mathrm{Ad}}$ & $80.00^{\mathrm{Bc}}$ & $75.00^{\mathrm{Bd}}$ & $95.50^{\mathrm{Aa}}$ & $80.07 \pm 6.53$ \\
Craftsmen & $75.00^{\mathrm{Ba}}$ & $45.00^{\mathrm{Cd}}$ & $42.50^{\mathrm{De}}$ & $47.50^{\mathrm{Bc}}$ & $35.00^{\mathrm{Cf}}$ & $42.50^{\mathrm{Ce}}$ & $57.50^{\mathrm{Bb}}$ & $49.29 \pm 9.69$ \\
Hunters & $20.00^{\mathrm{Dd}}$ & $37.50^{\mathrm{Db}}$ & $45.00^{\mathrm{Ca}}$ & $25.00^{\mathrm{Cc}}$ & $10.00^{\mathrm{De}}$ & $20.00^{\mathrm{Ed}}$ & $45.00^{\mathrm{Ca}}$ & $28.93 \pm 11.63$ \\
Blackmiths & $0.00^{\mathrm{Ff}}$ & $0.00^{\mathrm{Ff}}$ & $12.50^{\mathrm{Ec}}$ & $20.00^{\mathrm{Db}}$ & $2.50^{\mathrm{Ee}}$ & $25.00^{\mathrm{Da}}$ & $7.50^{\mathrm{Dd}}$ & $9.64 \pm 8.16$ \\
Fishermen & $10.00^{\mathrm{Eb}}$ & $12.50^{\mathrm{Ea}}$ & $12.50^{\mathrm{Ea}}$ & $5.00^{\mathrm{Ec}}$ & $0.00^{\mathrm{Fe}}$ & $2.50^{\mathrm{Fd}}$ & $0.00^{\mathrm{Ee}}$ & $6.07 \pm 4.80$ \\
\hline
\end{tabular}

Digits assigned the same capital letter of a column or the same miniscule letter of a line is not statistically different at the $5 \%$ threshold.

\section{Distribution of operators by gender}

Figure 2 shows the distribution of forest resource operators in the study sites by sex. The resource operators are mainly men (65.36\%), ie $57.50 \%, 75 \%, 65 \%, 62.50 \%, 85 \%$ and $70 \%$ in the villages Taa-tooyo, Gob-gabdo, Wack, Ndom Karna and Tchabbal respectively. The village Gop makes an exception with more than half (55\% of women). This is due to the multiple activities that men perform in relation to forest landscapes such as fishing, hunting, crafts, firewood trade and construction, and traditional pharmacopoeia, which are exclusive to the male sex. The high proportion of men may also be justified by the fact that these activities require a lot of energy and because in the traditional context, women are required to stay in households to perform certain domestic tasks. In addition, the Student's t-test reveals that there is a highly significant difference between the sexes $(0.035<0.05)$.

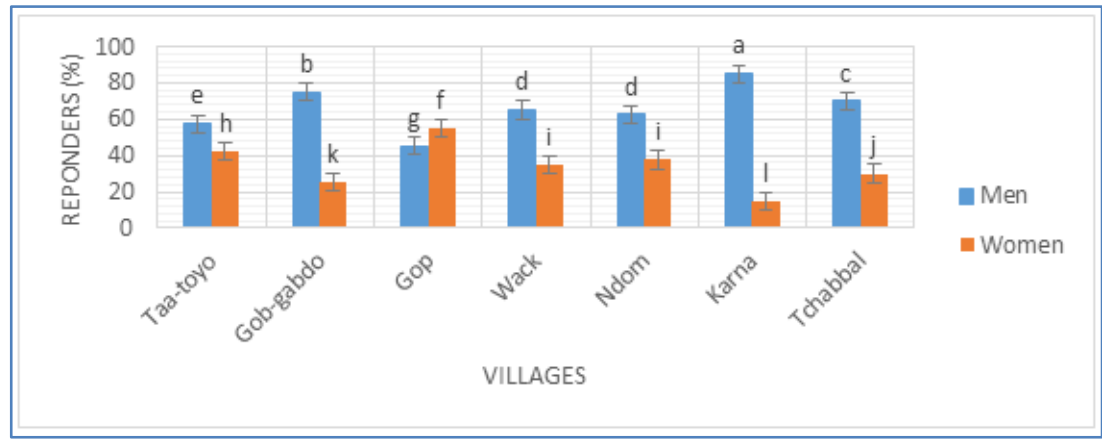

Fig-2: Resource distribution of operators by sex

The bands with the same letter indicate that the corresponding values are not statistically different at the $5 \%$ threshold. 


\section{Distribution of forest resource operators by age}

The distribution of the operators of vegetation exploitation according to their age is illustrated in Figure 3. It appears that the individuals having an age between 25 and 45 years $(61.79 \%)$ are the most represented. The extreme values of this age group are observed in Karna (40\%) and Taa-toyo (80\%) villages. Individuals aged 45 or older (15.36\%) are relatively less numerous on the farm. We note that in the villages Taa-tooyo and Gob-gabdo, this representativeness is zero. The youngest, less than 25 years of age, use forest resources moderately compared to others. However, at Wack and Ndom, their proportion is very small. Individuals under the age of 25 are not very interested in farming because they are too young and do not have too much responsibility. Among the operators, the individuals between 25 and 45 years old, mainly young people, are the most numerous because they have the energy necessary to carry out hard and difficult work. The analysis of variances shows that there is a very highly significant difference between age groups $(0.000<0.001)$.

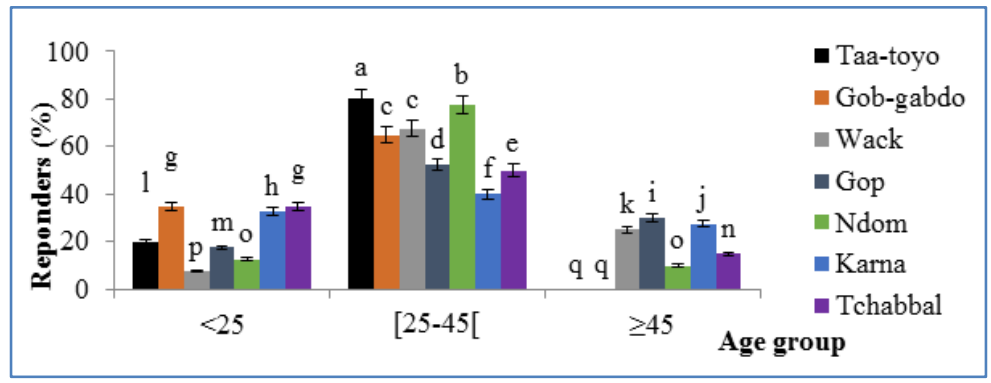

Fig-3: Distribution of farmers by age group

The bands with the same letter indicate that the corresponding values are not statistically different within $5 \%$.

\section{Distribution of forest resource operators by Ethnicity}

The forest resource operators are grouped into five ethnic groups unequally distributed in the different villages: Baya, Dii, Fulani, Mboum, Ngambaye and Toupouri (Figure 4). The majority actors are Dii represented in all the villages, followed by Baya, Fulani and Mboum, which are found in at least three villages. The Baya are present in the villages Gob-gabdo (17.50\%), Gop (5\%) and Tchabbal (22.50\%). The Fulani are found in villages Wack $(22.50 \%)$, Gop (15\%), Ndom (7.50\%), Karna $(20 \%)$ and Tchabbal (17.50\%). The Mboum are present in Wack (12.5\%), Karna (5\%) and Tchabbal (10\%). The Ngambaye and Toupouri, the least represented, settled in only two villages. This strong dominance of the Dii shows that they are the first occupants of Wack and Tchabbal. The other ethnic groups come from other localities where they found fertile lands for agropastoral activities. These are Toupouri who came from the Far North and settled in Taa-toyo village and others in Tchabbal for agricultural activities. The Fulani settled in these villages for their trade and breeding. The analysis of variances reveals a significant difference between ethnic groups $(0.016<0.05)$.

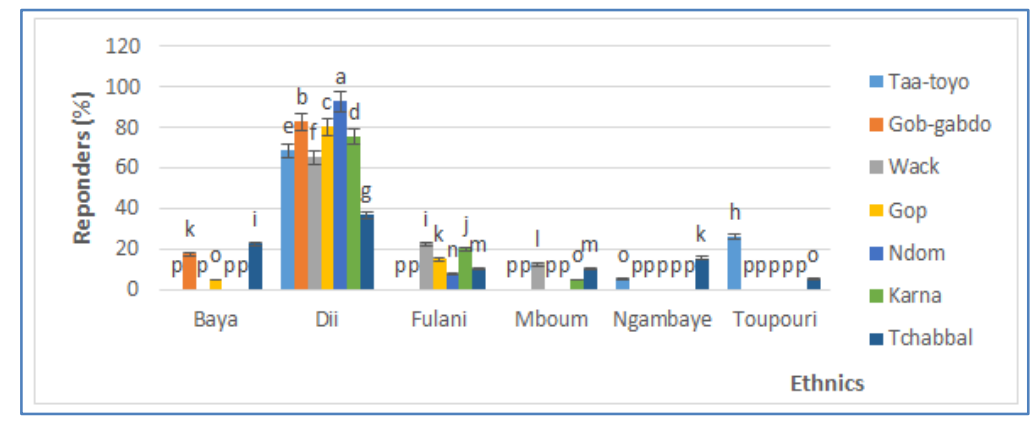

Fig-4: Distribution of farmers by ethnicity

The bands with the same letter indicate that the corresponding values are not statistically different within $5 \%$.

\section{Exploitation of NTFPs of plant origin as a food source}

Table 2 lists the woody species, sources of NTFPs used in human nutrition. In total, seventeen plant species provide the majority of NTFPs for consumption. Mangifera indica (100\%) and Borassus aethiopum (100\%) are the species most appreciated by local populations. They are followed by Tamarindus indica (93.57\%) and Vernonia amygdalina (86.00\%). Both species are appreciated by the entire population of Gop. Strychnos spinosa, the least exploited species as a food source, is appreciated by only $20 \%$ of the Taa-toyo population and $2.5 \%$ of the Karna population. Mangifera indica, an exotic species, is introduced into the cliff only by humans and the animals that consume it. On average, the village of Taa-tooyo (62.65\%) uses more food NTFPs than the villages Gob-gabdo (58.62\%), Karna (57.21\%), Gop (56.03\%), Wack (53.50\%), Tchabbal (51.32\%) and Ndom (49.76\%). Statistical analysis reveals a significant difference between species and between villages $(p<5 \%)$. 
Table-2: Proportion of woody species sources of NTFPs used in food (\%)

\begin{tabular}{|c|c|c|c|c|c|c|c|c|}
\hline $\begin{array}{l}\text { Villages } \\
\text { Species }\end{array}$ & $\begin{array}{l}\text { Taa- } \\
\text { tooyo }\end{array}$ & $\begin{array}{l}\text { Gob- } \\
\text { gabdo }\end{array}$ & Wack & Gop & Ndom & Karna & Tchabbal & Average \\
\hline Borassus aethiopum & 100.00 & 100.00 & 100.00 & 100.00 & 100.00 & 100.00 & 100.00 & $100.00 \pm 0.00^{a}$ \\
\hline Mangifera indica & 100.00 & 100.00 & 100.00 & 100.00 & 100.00 & 100.00 & 100.00 & $100.00 \pm 0.00^{a}$ \\
\hline Tamarindus indica & 100.00 & 80.00 & 87.50 & 100.00 & 90.00 & 97.50 & 100.00 & $93.57 \pm 6.63^{b}$ \\
\hline Vernonia amygdalina & 55.0 & 95.00 & 94.50 & 100.00 & 80.00 & 82.50 & 95.00 & $86.00 \pm 11.5^{c}$ \\
\hline Bombax costatum & 100.00 & 87.50 & 65.00 & 87.50 & 62.50 & 75.00 & 27.50 & $72.14 \pm 17.55^{d}$ \\
\hline Vitellaria paradoxa & 75.00 & 95.00 & 55.00 & 87.50 & 55.00 & 65.00 & 65.00 & $71.07 \pm 12.65^{d}$ \\
\hline Detarium microcarpum & 60.00 & 80.00 & 67.50 & 75.00 & 50.00 & 72.50 & 55.00 & $65.71 \pm 9.18^{e}$ \\
\hline Parkia biglobosa & 80.00 & 54.50 & 35.00 & 47.50 & 35.00 & 72.50 & 90.00 & $59.21 \pm 18.53^{f}$ \\
\hline Grewia flavescens & 85.00 & 60.00 & 35.00 & 72.50 & 65.00 & 45.00 & 42.50 & $57.86 \pm 14.59^{f}$ \\
\hline Sarcocephalus latifolius & 40.00 & 54.50 & 75.00 & 40.00 & 42.50 & 37.50 & 32.50 & $46.00 \pm 10.71 \mathrm{~g}$ \\
\hline Ximenia americana & 60.00 & 55.00 & 35.00 & 20.00 & 50.00 & 55.00 & 45.00 & $45.71 \pm 10.61 \mathrm{~g}$ \\
\hline Annona senegalensis & 40.00 & 47.50 & 60.00 & 35.00 & 25.00 & 65.00 & 45.00 & $45.36 \pm 10.41 \mathrm{~g}$ \\
\hline Ficus platyphylla & 47.50 & 40.00 & 60.00 & 27.50 & 45.00 & 35.00 & 32.50 & $41.07 \pm 8.37^{h}$ \\
\hline Syzygium sp. & 40.00 & 20.00 & 20.00 & 60.00 & 33.50 & 45.00 & 25,00 & $34.79 \pm 11.61^{i}$ \\
\hline Pterocarpus lucens & 47.50 & 7.50 & 20.00 & 0.00 & 12.50 & 7.50 & 5,00 & $14.29 \pm 11.12^{j}$ \\
\hline Neocarya macrophylla & 15.00 & 20.00 & 0.00 & 0.00 & 0.00 & 15.00 & 12,50 & $8.93 \pm 7.65^{\mathrm{k}}$ \\
\hline Strychnos spinosa & 20.00 & 0.00 & 0.00 & 0.00 & 0.00 & 2.50 & 0.00 & $3.21 \pm 4.80^{\prime}$ \\
\hline Average & $62.65 \pm$ & $58.62 \pm$ & $53.50 \pm$ & $56.03 \pm$ & $49.76 \pm$ & $57.21 \pm$ & $51.32 \pm 28.9 c$ & $55.58 \pm 24.15$ \\
\hline & $23.70^{a}$ & $26.89^{b}$ & & $32.73^{b}$ & $24.07^{d}$ & $25.30^{b}$ & & \\
\hline
\end{tabular}

Numbers assigned the same letter of the same row or column is not statistically different at the $5 \%$ threshold.

\section{Medicinal importance}

Table 3 summarizes the species used by local populations in traditional medicine. Fifteen species of listed medicinal plants testify to the importance given to the pharmacopoeia by the populations. Khaya senegalensis is the most exploited species with $68.93 \%$ followed by Vitellaria paradoxa (56.43\%). Ficus platyphylla is poorly used for health care $(5.71 \%)$. The high exploitation rate of Khaya senegalensis is due to its various healing properties. The results of the surveys revealed the many medicinal uses of this species by local populations. Indeed, the populations treat the toothache based on Khaya senegalensis. Some people use Khaya senegalensis to treat diarrhea. Others use it for the regulation of abundant and good quality breast milk production, burns, chronic weight loss and dysentery. The population of Taa-toyo (39.67\%) ranks first in the use of medicinal species. Then come the villages Wack (32.17\%), Karna (31.50\%) and Gob-gabdo (28\%). Operators in Ndom (24.07\%), Tchabbal (21.67\%) and Gop (18.67\%) villages use very little. Variance analysis reveals a significant difference between species and between villages $(p<5 \%)$.

Table 3: Proportion of woody species used in the traditional pharmacopoeia (\%)

\begin{tabular}{|c|c|c|c|c|c|c|c|c|}
\hline $\begin{array}{l}\text { Villages } \\
\text { Species }\end{array}$ & $\begin{array}{l}\text { Taa- } \\
\text { tooyo }\end{array}$ & $\begin{array}{l}\text { Gob- } \\
\text { gabdo }\end{array}$ & Wack & Gop & Ndom & Karna & Tchabbal & Average \\
\hline Khaya senegalensis & 67.50 & 47.50 & 80.00 & 65.00 & 80.00 & 85.00 & 57.50 & $68.93 \pm 10.92^{a}$ \\
\hline Vitellaria paradoxa & 87.50 & 67.50 & 55.00 & 35.00 & 45.00 & 55.00 & 50.00 & $56.43 \pm 12.04^{b}$ \\
\hline $\begin{array}{l}\text { Securidaca } \\
\text { longepedunculata }\end{array}$ & 75.00 & 47.50 & 65.00 & 45.00 & 40.00 & 60.00 & 42.50 & $53.57 \pm 11.22^{c}$ \\
\hline Anogeissus leiocarpus & 40.00 & 20.00 & 32.50 & 27.50 & 40.00 & 62.50 & 60.00 & $40.36 \pm 11.94^{d}$ \\
\hline Daniellia oliveri & 60.00 & 40.00 & 47.50 & 20.00 & 25.00 & 35.00 & 30.00 & $36.79 \pm 10.61^{\mathrm{e}}$ \\
\hline Burkea africana & 35.00 & 40.00 & 27.50 & 15.00 & 17.50 & 37.50 & 10.00 & $26.07 \pm 10.20^{f}$ \\
\hline Pterocarpus erinaceus & 27.50 & 12.50 & 40.00 & 20.00 & 37.50 & 12.50 & 12.50 & $23.21 \pm 10.10^{g}$ \\
\hline Gardenia aqualla & 55.00 & 20.00 & 27.50 & 20.00 & 12.50 & 5.00 & 5.00 & $20.71 \pm 11.73^{h}$ \\
\hline Afzelia africana & 50.00 & 35.00 & 12.50 & 5.00 & 12.50 & 5.00 & 10.00 & $18.57 \pm 13.67^{i}$ \\
\hline Dalbergia boehmii & 10.00 & 35.00 & 30.00 & 12.50 & 5.00 & 25.00 & 10.00 & $18.21 \pm 10.10^{i}$ \\
\hline Combretum glutinosum & 27.50 & 12.50 & 5.00 & 5.00 & 20.00 & 25.00 & 10.00 & $15.00 \pm 7.86 \mathrm{j}$ \\
\hline Bridelia scleroneura & 0.00 & 27.50 & 20.00 & 10.00 & 12.50 & 15.00 & 15.00 & $14.29 \pm 5.82^{k}$ \\
\hline Pseudocedrela kotschyi & 25.00 & 7.50 & 20.00 & 0.00 & 15.00 & 25.00 & 0.00 & $13.21 \pm 9.18^{\mid}$ \\
\hline Annona senegalensis & 15.00 & 7.50 & 0.00 & 0.00 & 7.50 & 25.00 & 12.50 & $9.64 \pm 6.73^{m}$ \\
\hline Ficus platyphylla & 20.00 & 0.00 & 20.00 & 0.00 & 0.00 & 0.00 & 0.00 & $5.71 \pm 8.16^{n}$ \\
\hline Average & $\begin{array}{l}39.67 \pm \\
20.98^{a}\end{array}$ & $\begin{array}{l}28.00 \pm \\
15.53^{\mathrm{d}}\end{array}$ & $\begin{array}{l}32.17 \pm \\
16.93^{b}\end{array}$ & $\begin{array}{l}18.67 \pm \\
13.589\end{array}$ & $\begin{array}{l}24.67 \pm \\
15.93^{e}\end{array}$ & $\begin{array}{l}31.50 \pm \\
19.47^{c}\end{array}$ & $\begin{array}{c}21.67 \pm \\
15.56^{f}\end{array}$ & $28.05 \pm 15.44$ \\
\hline
\end{tabular}

\section{Plant operation as firewood}

In total, twenty-four woody plant species are commonly used by local populations for firewood (Table 4). The most soughtafter species are Isoberlinia doka (66.07\%), Anogeissus leiocarpus (64.64\%), Daniellia oliveri (57.14\%). However, Bombax costatum $(3.21 \%)$, Grewia flavescens (5\%), Syzygium guineense var. macrocarpum (6.07\%) are less used as firewood. Some species are used only in two villages. This is for example Syzyguim guineense var. macrocarpum used only by $40 \%$ of the population of Wack and $2.50 \%$ of the population of Ndom and Bombax costatum exploited in the villages Gob-gabdo (7.50\%) and Wack (15\%). Others such as 
Sarcocephalus latifolius are exploited in four villages. This variation is confirmed by a significant difference in the $5 \%$ threshold between species and between villages $(P<5 \%)$.

Table-4: Proportion of woody species used as firewood by local populations (\%)

\begin{tabular}{|c|c|c|c|c|c|c|c|c|}
\hline $\begin{array}{l}\text { Villages } \\
\text { Species }\end{array}$ & $\begin{array}{l}\text { Taa- } \\
\text { tooyo }\end{array}$ & $\begin{array}{l}\text { Gob- } \\
\text { gabdo }\end{array}$ & Wack & Gop & Ndom & Karna & Tchabbal & Average \\
\hline Isoberlinia doka & 65.00 & 80.00 & 85.00 & 85.00 & 65.00 & 60.00 & 22.50 & $66.07 \pm 14.80^{a}$ \\
\hline Anogeissus leiocarpus & 65.00 & 80.00 & 85.00 & 27.50 & 62.50 & 70.00 & 62.50 & $64.64 \pm 11.84^{b}$ \\
\hline Daniellia oliveri & 80.00 & 40.00 & 60.00 & 65.00 & 45.00 & 27.50 & 82.50 & $57.14 \pm 16.84^{c}$ \\
\hline $\begin{array}{l}\text { Securidaca } \\
\text { longepedunculata }\end{array}$ & 27.50 & 47.50 & 60.00 & 52.50 & 37.50 & 50.00 & 45.00 & $45.71 \pm 7.76^{d}$ \\
\hline Hymenocardia acida & 55.00 & 35.00 & 65.00 & 25.00 & 45.00 & 50.00 & 42.50 & $45.36 \pm 9.69 d$ \\
\hline Khaya senegalensis & 12.50 & 67.50 & 27.50 & 45.00 & 65.00 & 45.00 & 55.00 & $45.36 \pm 14.69 d$ \\
\hline Burkea africana & 27.50 & 47.50 & 40.00 & 55.00 & 40.00 & 42.50 & 35.00 & $41.07 \pm 6.22^{\mathrm{e}}$ \\
\hline Pterocarpus lucens & 32.50 & 47.50 & 20.00 & 55.00 & 35.00 & 40.00 & 35.00 & $37.86 \pm 8.27^{f}$ \\
\hline Pterocarpus erinaceus & 20.00 & 40.00 & 45.00 & 25.00 & 25.00 & 35.00 & 32.50 & $31.79 \pm 7.24^{\mathrm{h}}$ \\
\hline Parkia biglobosa & 17.50 & 32.50 & 47.50 & 40.00 & 20.00 & 17.50 & 45.00 & $31.43 \pm 11.22^{\mathrm{h}}$ \\
\hline Terminalia laxiflora & 20.00 & 52.50 & 35.00 & 15.00 & 25.00 & 30.00 & 25.00 & $28.93 \pm 8.78 i$ \\
\hline Annona senegalensis & 32.50 & 40.00 & 15.00 & 20.00 & 25.00 & 30.00 & 12.50 & $25.00 \pm 7.86 j$ \\
\hline Mangifera indica & 20.00 & 27.50 & 0.00 & 27.50 & 15.00 & 32.50 & 30.00 & $21.79 \pm 8.67^{k}$ \\
\hline Pseudocedrela kotschyi & 15.00 & 40.00 & 7.50 & 35.00 & 25.00 & 12.50 & 12.50 & $21.07 \pm 10.51^{k}$ \\
\hline Vitex doniana & 20.00 & 40.00 & 7.50 & 15.00 & 22.50 & 17.50 & 12.50 & $19.29 \pm 7.04$ \\
\hline Bridelia scleroneura & 12.50 & 40.00 & 27.50 & 0.00 & 12.50 & 17.50 & 2.50 & $16.07 \pm 10.51^{m}$ \\
\hline Tamarindus indica & 10.00 & 35.00 & 0.00 & 20.00 & 12.50 & 5.00 & 15.00 & $13.93 \pm 8.06^{n}$ \\
\hline Ximenia americana & 40.00 & 12.50 & 27.50 & 7.50 & 0.00 & 0.00 & 10.00 & $13.93 \pm 11.33^{n}$ \\
\hline Strychnos spinosa & 7.50 & 27.50 & 32.50 & 0.00 & 0.00 & 0.00 & 2.50 & $10.00 \pm 11.43^{\circ}$ \\
\hline Ficus platyphylla & 7.50 & 25.00 & 0.00 & 0.00 & 7.50 & 15.00 & 5.00 & $8.57 \pm 6.53^{p}$ \\
\hline Sarcocephalus latifolius & 0.00 & 0.00 & 0.00 & 35.00 & 2.50 & 2.50 & 10.00 & $7.14 \pm 8.78 q$ \\
\hline Syzygium sp. & 0.00 & 0.00 & 40.00 & 0.00 & 2.50 & 0.00 & 0.00 & $6.07 \pm 9.69 r$ \\
\hline Grewia flavescens & 7.50 & 15.00 & 0.00 & 0.00 & 0.00 & 0.00 & 12.50 & $5.00 \pm 5.71^{\mathrm{s}}$ \\
\hline Bombax costatum & 0.00 & 7.50 & 15.00 & 0.00 & 0.00 & 0.00 & 0.00 & $3.21 \pm 4.59^{t}$ \\
\hline \multirow[t]{2}{*}{ Average } & $39.74 \pm$ & $43.09 \pm$ & $43.08 \pm$ & $36.24 \pm$ & $35.83 \pm$ & $39.46 \pm$ & $36.78 \pm$ & $39.17 \pm 2.24$ \\
\hline & $16.71^{\mathrm{b}}$ & $14.73^{\mathrm{a}}$ & $21.48^{a}$ & $18.53^{\mathrm{c}}$ & $16.50^{c}$ & $17.34^{b}$ & $17.47^{\mathrm{c}}$ & \\
\hline
\end{tabular}

The numbers assigned to the same letter of the same row or column is not statistically different at the $5 \%$ threshold.

\section{Importance for crafts}

Nine species are used as building materials, basket-making, hats, tablecloths and furniture (Table 5). Piliostigma thonningii $(85.36 \%)$ and Sterculia setigera (21.79\%) are used for ropes. Isoberlinia doka (63.21\%), Pterocarpus lucens (68.93\%), Terminalia laxiflora (70.36\%), Terminalia glaucescens (49.21\%), Daniellia oliveri $(37.14 \%)$, Afzelia africana (18.21\%) Serve as poles for the construction of houses, wood for the manufacture of Tam-tams as well as mortars. Analysis of variances shows a significant difference between the species used in crafts and between villages in the exploitation of resources $(0.000<0.001)$.

Table-5: Proportion of woody species used in crafts (\%)

\begin{tabular}{|c|c|c|c|c|c|c|c|c|}
\hline $\begin{array}{l}\text { Villages } \\
\text { Species }\end{array}$ & $\begin{array}{l}\text { Taa- } \\
\text { tooyo }\end{array}$ & $\begin{array}{l}\text { Gob- } \\
\text { gabdo }\end{array}$ & Wack & Gop & Ndom & Karna & Tchabbal & Average \\
\hline Piliostigma thonningii & 80.00 & 95.00 & 80.00 & 75.00 & 90.00 & 85.00 & 92.50 & $85.36 \pm 6.12^{a}$ \\
\hline Terminalia laxiflora & 55.00 & 80.00 & 67.50 & 80.00 & 72.50 & 62.50 & 75.00 & $70.36 \pm 7.45^{b}$ \\
\hline Pterocarpus lucens & 87.50 & 92.50 & 75.00 & 60.00 & 32.50 & 55.00 & 80.00 & $68.93 \pm 16.94$ \\
\hline Isoberlinia doka & 95.00 & 80.00 & 40.00 & 52.50 & 67.50 & 52.50 & 55.00 & $63.21 \pm 15.10^{d}$ \\
\hline Terminalia macroptera & 55.00 & 60.00 & 45.00 & 50.00 & 42.50 & 72.50 & 35.00 & $51.43 \pm 9.49 e$ \\
\hline Terminalia glaucescens & 60.00 & 80.00 & 25.00 & 52.50 & 35.00 & 27.50 & 64.50 & $49.21 \pm 17.18^{f}$ \\
\hline Daniellia oliveri & 20.00 & 35.00 & 47.50 & 27.50 & 60.00 & 45.00 & 25.00 & $37.14 \pm 11.73 \mathrm{~g}$ \\
\hline Sterculia setigera & 47.50 & 10.00 & 32.50 & 0.00 & 15.00 & 22.50 & 25.00 & $21.79 \pm 11.53^{h}$ \\
\hline Afzelia africana & 27.50 & 15.00 & 7.50 & 0.00 & 30.00 & 15.00 & 32.50 & $18.21 \pm 10.10^{i}$ \\
\hline Average & $\begin{array}{l}58.61 \pm \\
19.57^{c}\end{array}$ & $\begin{array}{l}60.83 \pm \\
27.41^{\mathrm{a}}\end{array}$ & $\begin{array}{l}46.67 \pm \\
18.52^{f}\end{array}$ & $\begin{array}{l}44.17 \pm \\
23.339\end{array}$ & $\begin{array}{l}49.44 \pm \\
20.49 e\end{array}$ & $\begin{array}{l}48.61 \pm \\
18.77^{d}\end{array}$ & $\begin{array}{l}53.83 \pm \\
21.74^{b}\end{array}$ & $51.74 \pm 5.16$ \\
\hline
\end{tabular}

The numbers assigned to the same letter of the same row or column is not statistically different at the $5 \%$ threshold. 


\section{NWFPs of animal and fungal origin}

NWFPs of animal and fungal origin have been identified (Table 6). So, thirteen types were identified. Termites (86.79\%) Are the most sought after by the populations in all the villages? They are consumed by all the surveyed populations of Taa-toyo and Tchabbal. Mushrooms (84.29\%) are the second most exploited NWFP. They enter into the preparation of the sauce and are marketed outside and inside the Adamawa region. In the villages Taa-toyo and Gob-gabdo, all populations are mycophagous. The preference of these two NWFPs is simply due to their easy accessibility. The low use of animals in this case the monkeys (Cercocebus albigena), the porcupine's pigs (Hystrix christata), the hares (Lepus capensis), the warthogs (Potamochoerus porkus), the pangolins (Manis giganthea) is since they are protected against human threats. The villages have the same rate of exploitation of NWFPs of animal and fungal origin. The population of Taa-Toyo (48.54\%) Uses more resources than Gob-gabdo (46.81\%), Tchabbal (45.88\%), Ndom $(45.88 \%)$, Karna (40\%), Wack (37.22\%) and Gop (31.88\%). Analysis of variances showed a significant difference between species and villages $(0.000<0.001)$.

Table-6: NWFPs of animal and fungal origin (\%)

\begin{tabular}{lcccccccc}
\hline \multicolumn{1}{c}{ Villages } & $\begin{array}{c}\text { Taa- } \\
\text { tooyo }\end{array}$ & $\begin{array}{c}\text { Gob- } \\
\text { gabdo }\end{array}$ & Wack & Gop & Ndom & Karna & Tchabbal & Average \\
\hline Termites & 100.00 & 87.50 & 80.00 & 60.00 & 92.50 & 87.50 & 100.00 & $86.79 \pm 9.59^{\mathrm{a}}$ \\
Mushrooms & 100.00 & 100.00 & 75.00 & 67.50 & 80.00 & 92.50 & 75.00 & $84.29 \pm 11.33^{\mathrm{b}}$ \\
Rats & 75.00 & 90.00 & 55.00 & 65.00 & 70.00 & 52.50 & 50.00 & $65.36 \pm 11.12^{\mathrm{c}}$ \\
Caterpillar & 67.50 & 57.50 & 65.00 & 60.00 & 42.50 & 75.00 & 65.00 & $61.79 \pm 7.24^{\mathrm{d}}$ \\
Birds & 67.50 & 26.67 & 20.00 & 20.00 & 85.00 & 45.00 & 100.00 & $52.02 \pm 27.55^{\mathrm{e}}$ \\
Locusts & 40.00 & 67.50 & 80.00 & 20.00 & 25.00 & 12.50 & 72.50 & $45.36 \pm 23.98^{\mathrm{f}}$ \\
Reptiles & 55.00 & 60.00 & 6.67 & 15.00 & 12.50 & 45.00 & 12.50 & $29.52 \pm 20.41 \mathrm{~g}$ \\
Hare & 20.00 & 12.50 & 17.50 & 27.50 & 25.00 & 15.00 & 15.50 & $19.00 \pm 4.43^{\mathrm{h}}$ \\
Monkeys & 17.50 & 20.00 & 10.00 & 10.00 & 25.00 & 10.00 & 25.00 & $16.79 \pm 5.82^{\mathrm{i}}$ \\
Warthogs & 15.00 & 27.50 & 10.00 & 10.00 & 15.00 & 12.50 & 10.00 & $14.29 \pm 4.18^{\mathrm{j}}$ \\
Porcupines & 15.00 & 5.00 & 10.00 & 17.50 & 15.00 & 20.00 & 12.50 & $13.57 \pm 3.78^{\mathrm{k}}$ \\
Pangolins & 10.00 & 7.50 & 17.50 & 10.00 & 15.00 & 12.50 & 12.50 & $12.14 \pm 2.55^{\mathrm{j}}$ \\
Average & $48.54 \pm$ & $46.81 \pm$ & $37.22 \pm$ & $31.88 \pm$ & $41.88 \pm$ & $40.00 \pm$ & $45.88 \pm$ & $41.74 \pm 27.49$ \\
& $28.96^{\mathrm{a}}$ & $30.28^{\mathrm{b}}$ & $28.15^{f}$ & $20.83 \mathrm{~g}$ & $26.77^{\mathrm{d}}$ & $26.25^{\mathrm{e}}$ & $31.21^{\mathrm{c}}$ & \\
\hline
\end{tabular}

The numbers assigned to the same letter of the same row or column are not statistically different at the $5 \%$ threshold.

\section{Market values of the forest resources of the cliff of Ngaoundéré}

The exploitation of forest products is intended not only for consumption but also for marketing. Table 7 lists the types of trade-involved forest products. It shows that $39.44 \%$ of the population is occupied by this activity. In addition, fuelwood is the first most marketed product with a prevalence rate of $59.64 \%$. It is followed by edible forest products and timbers with marketing rates of $40.81 \%$ and $17.86 \%$ respectively. The populations of Taa-Tooyo and Gob-gabdo are most interested in the commercialization of these resources. The abundant use of firewood as a source of energy is conditioned by its price and availability [27]. Forest products are sold in several forms and prices vary depending on the type of product (Table 8). Bush meat, for example, can only reach urban consumers in dried or smoked form. As for the prices, they range from 500 FCFA for the piece or package from $0.5 \mathrm{~kg}$ to 10000 FCFA for the whole game of $10 \mathrm{~kg}$. Fuelwood is sold in the form of charcoal or bundles of firewood. The resources of the Ngaoundéré cliff play an important role in the economy of the riparian populations. These incomes make it possible to partially fill the budget deficit of the sector's direct players. But the rate of marketing of these resources remains low. Most NWFPs in the forest formation of the cliff are used according to a livelihood strategy by the populations; Above all for their own consumption and possibly for an income that remains marginal.

Table-7: Types of forest products marketed by local populations

\begin{tabular}{lcccccccc}
\hline Villages & $\begin{array}{c}\text { Taa- } \\
\text { tooyo }\end{array}$ & $\begin{array}{c}\text { Gob- } \\
\text { gabdo }\end{array}$ & Wack & Gop & Ndom & Karna & Tchabbal & Average \\
Typical of the FP & & & & & & & & \\
\hline Energy Wood & 65.00 & 70.00 & 67.50 & 60.00 & 55.00 & 45.00 & 55.00 & $59.64 \pm 6.84^{\mathrm{a}}$ \\
Edible FP & 54.50 & 62.50 & 34.50 & 26.67 & 45.00 & 37.50 & 25.00 & $40.81 \pm 11.31^{\mathrm{b}}$ \\
Timber Construction & 27.50 & 20.00 & 7.50 & 12.50 & 15.00 & 22.50 & 20.00 & $17.86 \pm 5.31^{\mathrm{c}}$ \\
Average & $49.00 \pm$ & $50.83 \pm$ & $36.50 \pm$ & $33.06 \pm$ & $38.33 \pm$ & $35.00 \pm$ & $33.33 \pm$ & $39.44 \pm 5.99$ \\
& $14.33^{\mathrm{b}}$ & $20.56^{\mathrm{a}}$ & $20.67^{\mathrm{d}}$ & $17.96^{f}$ & $15.56^{\mathrm{c}}$ & $8.33^{\mathrm{e}}$ & $14.44^{f}$ & \\
\hline
\end{tabular}

The numbers assigned from the different letter of the same row or column is statistically different at the $5 \%$ threshold. 
Table-8: Types, forms and prices of marketed forest products

\begin{tabular}{lll}
\hline Forest Products & Marketing Forms & Unit Price (FCFA) \\
\hline Firewood & Bundle & $100-200$ \\
Wood Charcoal & Heap, 100 kg bag & $50-3000$ \\
Medicinal products & In glass, sachet of juice, powder & $100-500$ \\
Fruits & Fleshy fruits, dry & $25-100$ \\
Vegatables & Flesh, dry & $25-50$ \\
Wood construction & Bundle & $2000-3000$ \\
Insects & In fresh pile, dry & $100-200$ \\
Game & Fresh meat, dry, smoked & $100-10000$ \\
Mushrooms & In fresh pile, dry & $100-200$ \\
\hline
\end{tabular}

\section{Perception of cliff degradation and associated phenomena}

Most riparian populations perceive the decrease in the vegetation cover of the Ngaoundéré cliff. Only $5.72 \%$ of respondents observed vegetation stability in the last twenty years (Figure 5). The phenomena associated with this degradation include the decrease in rainfall $(95.42 \%)$, the decline in agricultural productivity $(93.46 \%)$, the increase in drought $(87.71 \%)$, the increase in temperature $(86.85 \%)$, the decrease in the plant productivity $(82.85 \%)$, water drainage $(45.71 \%)$, the regularity of floods $(43.74 \%)$ (Table 9). The statistical analysis reveals a significant difference between the various consequences of the degradation of vegetation cover perceived by local populations $(0.03<0.05)$.

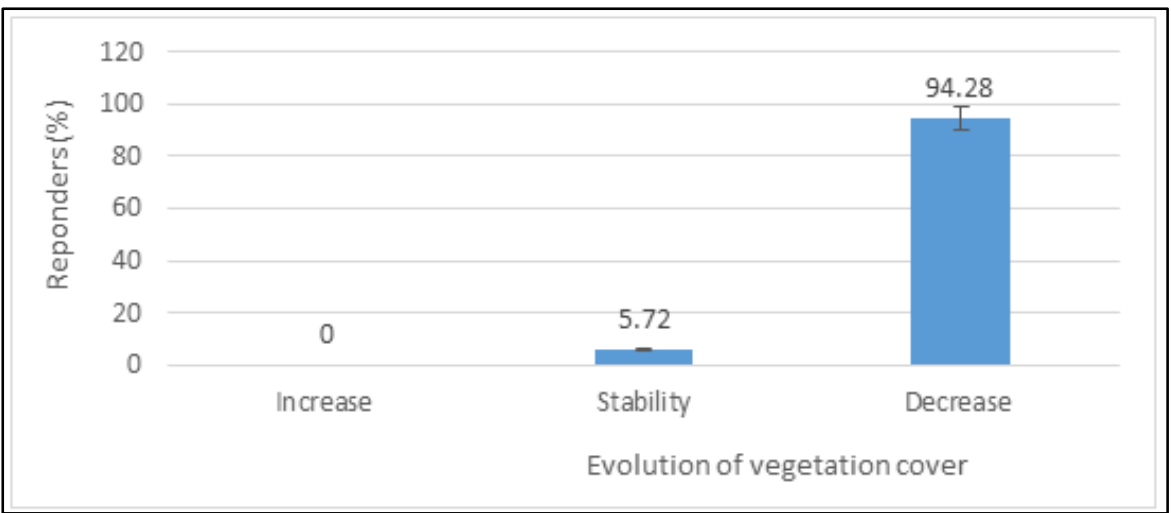

Fig-5: Perceptions of local populations on the evolution of vegetation cover

Table-9: Rate of phenomena associated with the degradation of vegetation cover (\%)

\begin{tabular}{lcccccccc}
\hline \multicolumn{1}{c}{ Villages } & $\begin{array}{c}\text { Taa- } \\
\text { toyo }\end{array}$ & $\begin{array}{c}\text { Gob- } \\
\text { gabdo }\end{array}$ & Gop & Wack & Ndom & Karna & Tchabbal & Average \\
\hline Pecrease in rainfall & 100.00 & 98.00 & 98.00 & 90.00 & 96.00 & 92.00 & 94.00 & $95.42 \pm 3.59^{\mathrm{a}}$ \\
$\begin{array}{l}\text { Reducing agricultural } \\
\text { productivity }\end{array}$ & 87.50 & 90.00 & 98.00 & 100.00 & 91.83 & 93.47 & 93.48 & $93.46 \pm 4.34^{\mathrm{a}}$ \\
$\begin{array}{l}\text { Increase in drought } \\
\text { Temperature increase }\end{array}$ & 96.00 & 94.00 & 90.00 & 84.00 & 86.00 & 68.00 & 96.00 & $87.71 \pm 9.89^{\mathrm{b}}$ \\
$\begin{array}{l}\text { Decrease in plant } \\
\text { productivity }\end{array}$ & 94.00 & 94.00 & 70.00 & 90.00 & 84.00 & 84.00 & 92.00 & $86.85 \pm 8.55^{\mathrm{b}}$ \\
Water drainage & 90.00 & 84.00 & 90.00 & 64.00 & 90.00 & 82.00 & 80.00 & $82.85 \pm 9.29^{\mathrm{c}}$ \\
Regularity of floods & 50.00 & 48.00 & 58.00 & 44.00 & 52.00 & 38.00 & 30.00 & $45.71 \pm 9.34 \mathrm{~d}$ \\
Average & 44.00 & 52.00 & 40.00 & 48.00 & 36.00 & 44.00 & 42.00 & $43.71 \pm 5.21^{\mathrm{d}}$ \\
& $80.21 \pm 2$ & $80.00 \pm 2$ & $77.70 \pm 2$ & $74.29 \pm 2$ & $76.55 \pm 2$ & $71.63 \pm 2$ & $75.35 \pm 27.6$ & $76.53 \pm 2.67$ \\
\hline
\end{tabular}


The numbers assigned to the same letter of the same row or column is not statistically different at the $5 \%$ threshold.

\section{Traditional vegetation management methods}

The exploitation of plant resources is an important part of the local community. The protection strategies developed by the populations are less to care about the environment than to make the most of this potential. Table 10 presents traditional methods for the development of cliff vegetation by riparian populations. It is clear from this table that the populations contribute to the conservation of the vegetation. Customary practices $(51.07 \%)$ are the most important means of conservation by local people. The conservation of village forest relics known as sacred wood for cultural or religious purposes is practised at least by half of the population in all villages except for Gop and Tchabbal, where most populations do not give importance to customary practices. Traditional regulation through the organisation of hunting and fishing $(50.36 \%)$ at a given time is the second means of preserving biodiversity to limit and regulate the exploitation of animal resources at any time. In addition to these two protective measures, the introduction of species through the creation of fruit tree plantations (24.64\%) to alleviate a shortfall at economic, sociocultural and scientific level, case gardens (30.71\%), the creation of agroforestry systems $(22.86 \%)$ For the maintenance of soil fertility or for the supply of forest products to humans. Unlike the populations of other villages, those of Taa-Tooyo (21\%) and Gop $(26.50 \%)$ contribute less to the conservation and preservation of biodiversity. Analysis of variances reveals a significant difference between the methods undertaken by the local population and between sites $(0.000<0.001)$.

Table-10: Traditional approaches to the development of the cliff by local populations (\%)

\begin{tabular}{lcccccccc}
\hline \multicolumn{1}{c}{ Villages } & $\begin{array}{c}\text { Taa- } \\
\text { toyo }\end{array}$ & $\begin{array}{c}\text { Gob- } \\
\text { gabdo }\end{array}$ & Wack & Gop & Ndom & Karna & $\begin{array}{c}\text { Tchabb } \\
\text { al }\end{array}$ & Average \\
\hline $\begin{array}{l}\text { Customary practices (sacred } \\
\text { wood) }\end{array}$ & 50.00 & 55.00 & 52.50 & 42.50 & 57.50 & 72.50 & 27.50 & $51.07 \pm 9.49^{\mathrm{a}}$ \\
Traditional regulation & & & & & & & & \\
Garden case & 20.00 & 65.00 & 60.00 & 40.00 & 32.50 & 60.00 & 75.00 & $50.36 \pm 16.73^{\mathrm{a}}$ \\
Planting fruit trees & 12.50 & 7.50 & 52.50 & 35.00 & 35.00 & 40.00 & 32.50 & $30.71 \pm 11.84^{\mathrm{b}}$ \\
Agroforestry systems & 7.50 & 32.50 & 30.00 & 10.00 & 25.00 & 25.00 & 42.50 & $24.64 \pm 9.08^{\mathrm{c}}$ \\
Average & 15.00 & 5.00 & 12.50 & 5.00 & 32.50 & 45.00 & 45.00 & $22.86 \pm 15.41^{\mathrm{d}}$ \\
& $21.00 \pm$ & $33.00 \pm$ & $41.50 \pm$ & $26.50 \pm$ & $36.50 \pm$ & $48.50 \pm$ & $44.50 \pm$ & $35.93 \pm 11.83$ \\
& $11.60 \mathrm{~g}$ & $21.60^{\mathrm{e}}$ & $16.20^{\mathrm{c}}$ & $15.20^{\mathrm{f}}$ & $8.40^{\mathrm{d}}$ & $14.20^{\mathrm{a}}$ & $12.40^{\mathrm{b}}$ & \\
\hline
\end{tabular}

The numbers assigned to the same letter of the same row or column is not statistically different at the $5 \%$ threshold.

\section{Co-management measures}

Table 11 presents the measures for co-management of cliff vegetation by riparian populations. The ban on the production of coal $(100 \%)$, the penalties for illegal holdings $(100 \%)$, the ban on the levying of green timber $(68.21 \%)$, the raising of the population on the practice of bush fires $(49.36 \%)$ are the management methods applied by local populations to limit the anarchic exploitation of natural resources to ensure their sustainability. The statistical analysis detected a significant difference between the different methods of co-management and between sites $(0.000<0.001)$.

Table-11: Methods of co-management of forest landscapes (\%)

\begin{tabular}{|c|c|c|c|c|c|c|c|c|}
\hline Methods of co-management & $\begin{array}{l}\text { Taa- } \\
\text { toyo }\end{array}$ & $\begin{array}{l}\text { Gob } \\
\text { gabdo }\end{array}$ & Wack & Gop & Ndom & Karna & Tchabbal & Average \\
\hline Sanctions for illegal operators & 100.00 & 100.00 & 100.00 & 100.00 & 100.00 & 100.00 & 100.00 & $100.00 \pm 0,00^{a}$ \\
\hline Prohibition of coal production & 100.00 & 100.00 & 100.00 & 100.00 & 100.00 & 100.00 & 100.00 & $100.00 \pm 0,00 a$ \\
\hline $\begin{array}{l}\text { Raising awareness on green } \\
\text { wood harvesting }\end{array}$ & 80.00 & 87.50 & 47.50 & 60.00 & 75.00 & 77.50 & 50.00 & $68.21 \pm 13,47^{b}$ \\
\hline Awareness of fire practice & 20.00 & 72.50 & 55.00 & 53.00 & 42.50 & 30.00 & 72.50 & $49.36 \pm 15,88 c$ \\
\hline National capacity building & 0.00 & 0.00 & 35.00 & 12.50 & 20.00 & 25.00 & 7.50 & $14.29 \pm 10,61^{d}$ \\
\hline Reforestation of local plants & 0.00 & 5.00 & 0.00 & 5.00 & 15.00 & 65.00 & 2.50 & $13.21 \pm 15,31^{d}$ \\
\hline Limiting intensive agriculture & 0.00 & 2.50 & 5.00 & 2.50 & 12.50 & 10.00 & 0.00 & $4.64 \pm 3,88^{\mathrm{e}}$ \\
\hline Cliff Certification & 5.00 & 5.00 & 0.00 & 0.00 & 5.00 & 0.00 & 12.50 & $3.93 \pm 3,37 \mathrm{e}$ \\
\hline Cliff Operating Permit & 0.00 & 0.00 & 5.00 & 5.00 & 0.00 & 0.00 & 0.00 & $1.43 \pm 2,04^{f}$ \\
\hline Average & $\begin{array}{l}33.89 \pm \\
39.63^{d}\end{array}$ & $\begin{array}{l}41.39 \pm \\
43.21^{b}\end{array}$ & $\begin{array}{l}38.61 \pm \\
32.90^{c}\end{array}$ & $\begin{array}{l}37.56 \pm \\
36.17^{c}\end{array}$ & $\begin{array}{l}41.11 \pm \\
34.01^{b}\end{array}$ & $\begin{array}{l}45.28 \pm \\
35.86^{\mathrm{a}}\end{array}$ & $\begin{array}{l}8.30 \pm 3 \\
37.59 \mathrm{e}\end{array}$ & $39.45 \pm 37,05$ \\
\hline
\end{tabular}

The numbers assigned to the same letter of the same row or column is not statistically different at the $5 \%$ threshold.

\section{DISCUSSION}

The vegetation of the cliff of Ngaoundéré is highly exploited for agriculture, breeding and forest products that are not woody and woody. The main actors of this exploitation are the men. Similar results were obtained in the peri-urban savannas of Ngaoundéré 
by Tchobsala [28] which showed that it is the men who are most involved in the exploitation of the woods. Among the men who exploit the vegetation of the cliff, the young are the most numerous because they still have energy to carry out hard and arduous work. Similar results were found by MINEF [29] in the Mayo-Louti, which showed that young people are the most active in the exploitation of plant resources. In addition to the natives of the seven villages in the study area, transhumane shepherds and poachers are not the least in the exploitation of the cliff vegetation.Many people exploit the vegetation of the cliff of Ngaoundéré to obtain non-wood forest products for food, service, trade, health, handicrafts, firewood etc. to reduce the unemployment rate in the seven villages. In general, operators use these natural resources to treat themselves to the native, as this plant formation is a natural, imperishable and inexhaustible pharmacy, at a lower cost to humans [22]. Further work was obtained by Tchobsala [28] in the peri-urban savannahs of Ngaoundéré, which showed that several species such as Annona senegalensis, Khaya senegalensis, Securidaca longepedunculata, Fagara senegalensis etc. are used in traditional Pharmacopoeia. Dongock and et al. [2] have shown that species such as Ximenia americana and Tamarindus indica are highly sought after as firewood and the to produce coal in the Sudano-sahelian zone of Chad. But the rate of marketing of these resources remains low. Most NWFPs in the cliff vegetation are used according to a population subsistence strategy; above all for their own consumption and possibly for an income that remains marginal. According to FAO [8], these products are essential for the livelihood of populations dependent on forest landscapes and reduce poverty. The very significant consumption of fuelwood by the population is an indicator of the depletion of trees in the cliff. In the same vein, Mapongmetsem and Akagou [30] reported that the situation of fuelwood is already alarming in the Adamawa in the years 97. Some families use mushrooms as food and traditional sources. Similar results were obtained by Toirambe [31] in the Democratic Republic of the Congo. He showed that in all the households visited during his study, more than half of the population harvests the mushrooms that are part of their food tradition. It is according to Ramakrahnan [32] that, in the Sudano-Guinean savannas, the income derived from the exploitation of NWFPs such as plant products and animals, although still poorly estimated, would be about twenty billion a year. The income allows to partially fill the budget deficit of the direct actors of the sector. To ensure the sustainability of these resources to satisfy future generations thus remedy the problem of overexploitation of the natural resources of the vegetation of the cliff of Ngaoundéré and its environs, a development plan including the local population and the Cameroonian government in charge of forests and wildlife was developed. Participatory co-management measures are being taken by the local populations and the ministries responsible for forests for sustainable management and conservation of biodiversity. These results corroborate those of Ntoupka [33] in the Sudano-Sahelian zone at Laf, which showed that populations are far from passive actors in the face of degradation through reforestation and planting of fruit trees.

\section{CONCLUSION}

The study on the exploitation of natural resources on the biodiversity of the Ngaoundéré cliff shows that farmers, breeders, craftsmen, hunters are the main actors in the exploitation of natural resources. The products are used in food, traditional medicine, crafts, and trade. Co-management is an effective measure used to safeguard the vegetation of the anthropization.

\section{ACKNOWLEDGEMENTS}

We extend our heartfelt thanks to the people on the cliffs and to the administrative authorities surveyed for facilitating the maintenance work.

\section{REFERENCES}

1. Eba'a A. R., Lescuyer, G., Poufoun, J. N. (2011). Etude de l'importance économique et sociale du secteur forestier et faunique dans les Etats de l'Afrique Centrale : Cas du Cameroun, $9 p$.

2. Dongock, N. D., Mapongmetsem, P. M., Mahamat, A., \& Noiha, N. N. (2017). Ethnological studies on melliferous plants of Soudano-Sahelian Zone of Chad. Journal of Medicinal Plants Studies, 5(3): 193-198.

3. FAO. (2007). Situation des Forêts du monde 2007. FAO, Rome, Italy, 22p.

4. Fahrig, L. (2003). Effets of habitat fragmentation on biodiversity. Annual Review of Ecology, Evolution and Systematics, 34: 487515.

5. Greenpeace. (2011). Bassin du Congo, forêts en sursis, http:// www.grrenpeace;fr/forêts-en-sursis/ bassin du Congo-forêts-ensursis. 137p.

6. Ibrahima, A. et Abib, Fanta, C. (2008). Estimation du stock de carbone dans les faciès arborées et arbustives des savanes soudano-guinéennes de Ngaoundéré, Cameroun. In Cameroon journal of experimental Biology, 4(1):1-11.

7. Tchobsala, N. D. Dongock, J. Nyasiri., \& A. Ibrahima. (2016a). Carbon storage of anthropoid's vegetation on the Ngaoundere escarpment (Adamawa, Cameroon). Journal of Advances in Biology, 9(2): 2347-6893.

8. FAO. (1999). Traditional foots plants. FAO foot and nutrition paper, 42: 1-592.

9. Ruiz, P.M., Ndoye, O., \& Eyebe, A. (1999). Marketing of non-woods forest products in the humid forest zone of Cameroon. Unsylva, 198:12-19.

10. Ndoye, O. (2005). Commercial issues related to non-timber forest products. In: Pfund J. L., Robinson P. (ed). Non-timber forest products between poverty alleviation and markets forces. Berne, Suisse, intercooperation, 14-19.

11. Clark, D. A. (2007). Detecting tropical forests' responses to global climatic and atmospheric change: current challenges and a way forward. Biotropica, 39:4-19 
12. Tchatat, M., Puig H. et Tiki, Manga, T. (1995). Les jardins de case des provinces du Centre et du Sud du Cameroun : description et utilisation d'un système agroforestier traditionnel journal d'agriculture traditionnelle et de Botanique appliquée, 37(2): 165-182.

13. Lescuyer, G. (2000). Evaluation économique et gestion viable de la forêt tropicale. Réflexion sur un mode de coordination des usages d'une forêt de l'Est-Cameroun. Thèse, école des hautes études en Sciences sociales, Paris, France, 417p.

14. FAO. (2001). Programme de coopération technique, bilan des expériences et modèle d'aménagement pour une gestion durable des forêts, Cameroun, 70p.

15. Tchotsoua, M. (996). L'homme et la dynamique des paysages sur la dorsale de l'Adamaoua. Le flambouyant $n^{\circ} 50: 26-39$.

16. Tchotsoua, M. (2006). Évolution récente des territoires de l'Adamaoua central: de la spatialisation à l'aide pour un développement maitrisé. Université d'Orléans. École doctorale Sciences de l'homme et de la société. HDR en GéographieAménagement-Environnement, 267p.

17. Ibrahima, A., Mapongmetsem, P. M. et Hassan, M. (2006). Influence de quelques facteurs zoo-anthropiques sur la phytodiversité ligneuse des savanes soudano-guinéennes de l'Adamaoua, Cameroun, $6 p$.

18. MINEPAT. (2002). Schéma directeur régional d'aménagement et de développement durable du territoire, Province de l'Adamaoua, 16p.

19. Tchuenguem, F. F. N. (2005). Activités de butinage et pollinisation de Apis mellifera adansonii Latreille sur les fleurs de trois plantes à Ngaoundéré: Callistemom rigidus (Myrtaceae), Syzyguim guineense var macrocarpum (Myrtaceae) et Voacanga africana (Apocynaceae). Thèse de Doctorat, Université de Yaoundé I. 123p.

20. Mapongmetsem, P. M. (2005). Phénologie et apports aux sols des substances biogènes par la litière de quelques fruitiers sauvages des savanes soudano-guinéennes. Thèse de Doctorat d'Etat ès Sciences Biologiques. Université de Yaoundé I, 242p.

21. Tchobsala, Ibrahima, A., Dongock N. D., \& Nyasiri J. (2016b). The impact of anthropisation on the floristic composition, the structure and ecological characterization of the Ngaoundéré Cliff, Cameroon. Global journal of Science Frontier Research Biological, 16(3): 2249-4626.

22. Nyasiri, J. (2018). Anthropisation et dynamique spatio-temporelle des paysages forestiers de la falaise de Ngaoundéré (Adamaoua-Cameroun). Thèse de Doctorat/Ph.D, Spécialité : Botanique et Ecologie, Faculté des Sciences, Université de Ngaoundéré. 180p.

23. Nyasiri, J., Tchobsala, Dongock, N. D., \& Ibrahima, A. (2018). Impact of anthropization on the spatio-temporal dynamics of the forest landscapes of the Ngaoundéré cliff, Adamawa-Cameroon. Int. J. Adv. Res. Biol. Sci. 5(3): 60-74.

24. MINEF. (1994). Diagnostic général de la situation de l'environnement dans la province de l'Adamaoua. Document de base PNUD/GTZ/BM. 143p.

25. Boutrais, J. (1998). L'agro-élevage des Foulbés de Ngaoundéré (Adamaoua camerounais). Les évolutions des relations entre l'agriculture et l'élevage. In Fertilité et relations agricultures-élevage en zone de savane. CIRAD: Montpellier, 107-121.

26. Yonheu, S. (1993). Végétation des pâturages de l'Adamaoua (Cameroun). Ecologie et potentialité pastorales. Thèse Doctorat, Sciences Biologiques. Univ. Rennes I. France, 207p.

27. Fonds de Partenariat pour le Carbone Forestier (FCPF). (2012). Proposition de mesures pour l'état de préparation (R-PP), programme de coopération des Nations Unies pour la réduction des émissions dues au déboisement et à la dégradation des forêts dans les pays en développement (ONU-REDD) Cameroun, Septembre, 157p.

28. Tchobsala. (2011). Impact des coupes de bois sur la végétation naturelle de la zone périurbaine de Ngaoundéré (Adamaoua). Thèse de Doctorat. Université de Yaoundé I. 184p.

29. MINEF. (2002). Inventaire ornithologique de la reserve forestière du Mayo-Louti et du parc de national de Mozogo-Gokoro, rapport technique et synthèse de l'avifaune. $16 p$.

30. Mapongmetsem, P. M et Akagou, Z. C. H. (1997). Situation de bois de feu dans les savanes humides de l'Adamaoua. Flambouyant, 42: 29-33.

31. Toirambe, B. (2005). Analyse de l'état des lieux du secteur des PFNL et évaluation de leur contribution à la sécurité alimentaire en République Démocratique du Congo, 88p.

32. Ramakrahnan, P.S. (1992). Forêts tropicales : exploitation, conservation et gestion. Impact Science et Société, Nº166, 415.

33. Ntoupka, M. (1999). Influence des perturbations anthropiques (pâturages, feu et coupes de bois) sur la dynamique de la savane arbre en zone soudano-sahélienne du Nord Cameroun, 226p. 